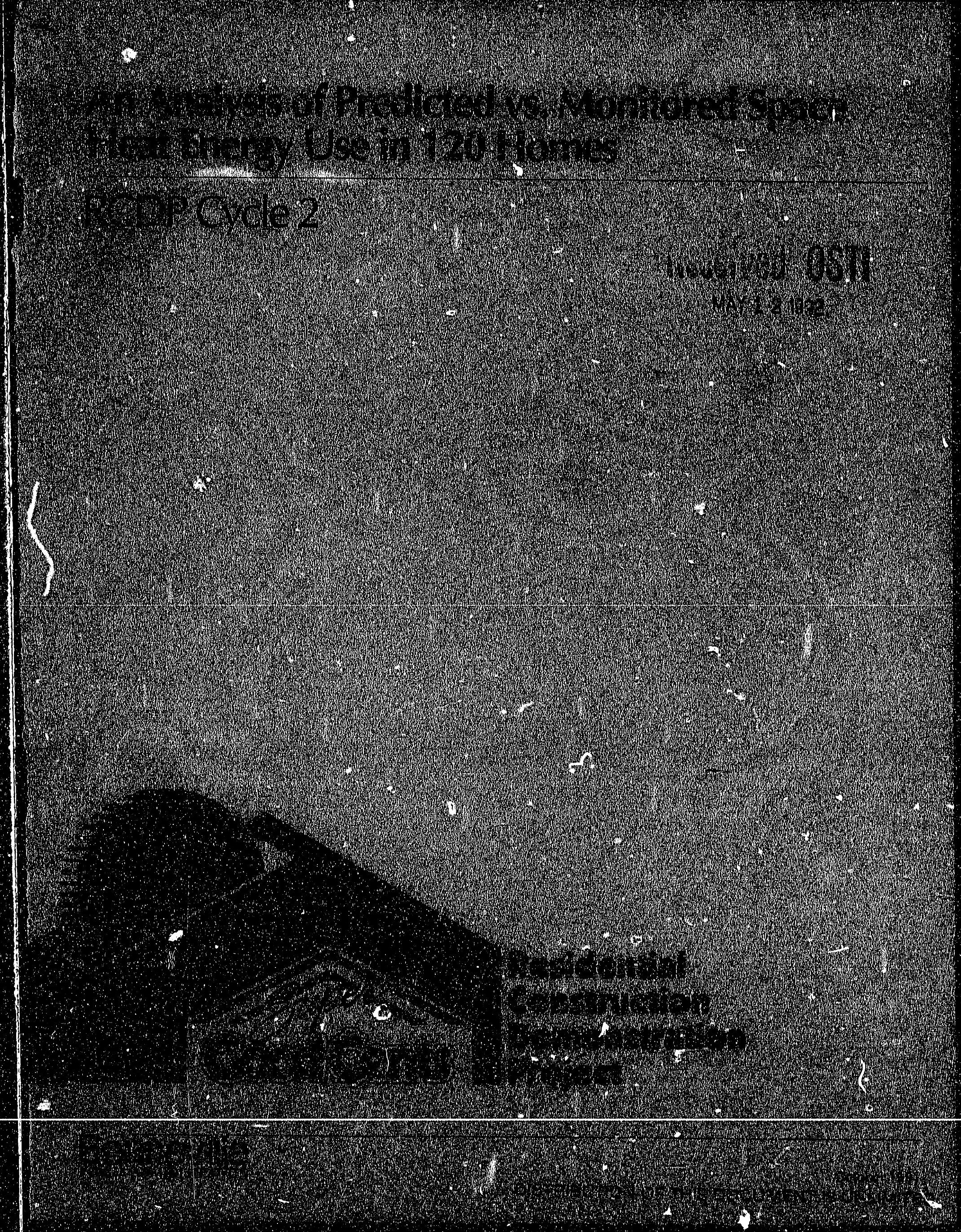




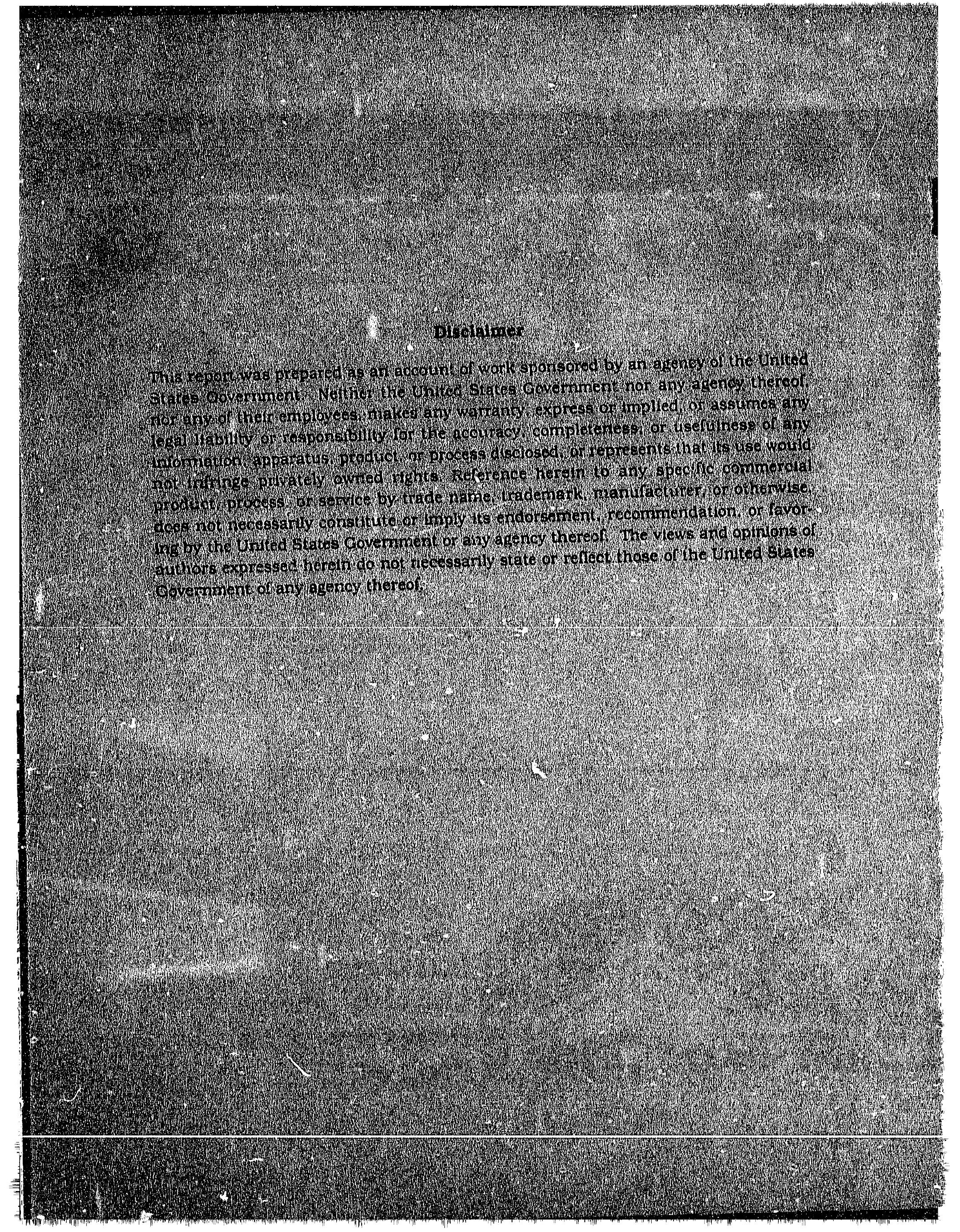




\section{An Analysis of Predicted vs. Monitored Space Heat Energy Use in 120 Homes}

Residential Construction

Demonstration Project Cycle II October 1991

John G. Douglass Marvin Young 


\section{Executive Summary}

The Model Conservation Standards are based on simulated performance of homes using the SUNDAY thermal simulation program. Several prior studies have assessed the ability of SUNDAY to predict space heat energy consumption. The Washirigton State Energy Office found good agreement between SUNDAY predictions and tnonitored performance for 282 homes located in Washington State that were constructed in the Residential Standards Demonstration Program, and for 83 homes in the northwest region that were constructed in the Residential Construction Demonstration Project (RCDP) Cycle I. A University of Washington team also validated SUNDAY in a detailed comparison of predicted and monitored performance in four tes' homes.

Controversy has diminished concerning SUNDAY's ability to accurately predict space heat energy consumption without bias. However, the model has not hitherto been valisated sufficiently for predicting the performance of houses with non-heat-recovery ventilators. In this second cycle of RCDP, the SUNDAY thermal simulation program was used to predict space heat energy consumption for 120 energy efficient homes. Most had non-heat-recovery ventilators. There was hope of validating SUNDAY's ability to predict energy performance in these homes. SUNDAY's performance with the RCDP Cycle II homes was indeed validated, with results consistent with prior comparative studies.

Several other variables that were not directly included as inputs to the simulation were examined with an analysis of covariance model. The objective was to see if an empirical adjustment could improve the simulation's prediction of space heat. The variables hav. ing the greatest effect were conditioned floor area, heating system type, and foundation type. By including them, the model was able to create a better match of predicted to monitored. Unmodified, SUNDAY algorithms explained 44 percent of the variation between predicted and monitored results. Modified by the covariance model, SUNDAY explained 67 percent of the variation. Including ventilation system type (i.e heat recovery or not) in the model did not significantly improve the match of predicted to monitored. Likewise, including an index of conservation robustness (overall UA per square foot of floor area) ctid not improve the match. This implies that SUNDAY needs no adjustment to accomodate variation in these parameters.

As prior studies have shown, SUNDAY is able to accurately predict mean space heat consumption of houses in aggregate. As with any building model that does not schedule individual occupant-related loads, there is considerable variation among inctividual houses. This is akin to the caveat usually placed in automobile gas mileage reports, "Your own mileage may vary...". 
In 1980 Congress passed the Northwest Electric Power Planning and Conservation Act. The Act established the Northwest Power Planning Council (NWPPC) and directed it to create a set of model conservation standards (MCS) based on regional cost-effective conservation measures for residential and commercial construction.

In 1983 the NWPPC directed the Bonneville Power Administration to create the Residential Standards Demonstration Program. The program's purpose was to demonstrate construction of the MCS and collect cost and themal data in residential structures. Much information was gained from that program, and as a consequence the MCS were reevaluated and updated. A second program, the Residential Construction Demonstration Project, was created to further investigate residential energy efficiency measures for both cost and thermal performance. This analysis was based upon information collected during the second cycle of the Residential Construction Demonstration Project.

The MCS is a set of performance requirements that vary depending on climate. Three climate zones defined by heating degree days $\left(65^{\circ} \mathrm{F}\right.$ base) were established. Table 1 lists climate zones and corresponding degree days.

\section{Table 1 Paclific Northwest Cllmate Zones}

\begin{tabular}{|c|c|}
\hline Climigte Zone & Heating Degree Days \\
\hline Zone 1 & $<6000$ \\
\hline Zone 2 & $600(0-8000$ \\
\hline Zone 3 & $>8000$ \\
\hline
\end{tabular}

The Model Conservation Standards are based on simulated performance of homes determined by using the SUNDAY thermal simulation program. Several studies have been undertaken to assess the ability of SUNDAY to predict space heat energy consumption. The Washington State Energy Office found good agreement between SUNDAY predictions and monitored performance for 282 homes located in Washington state and constructed in the Residential Standards Demonstration Program (Byers, 1988), and for 83 homes in the northwest region constructed in the Residential Construction Demonstration Project Cycle I, (Downey, 1989). A University of Washington team tested metered energy performance in four residences against predictions of SUNDAY and other simulation models. The team concluded that the comparisons validated the different simulation programs and conferred a sense of accuracy upon them (Emory, et.al, 1989). Older studies have shown SUNDA Y predictions to be as much as 30 percent high (Yoder, 1986). Controversy surrounding SUNDAY's ability to accurately predict space heat energy ccisumption without bias has diminished. However, it has been noted that the model has not been validated sufficiently f "iredicting performance of houses with nonheat-recovery ventilators.

The purpose of this study is to examine the relationship between SUNDAY predicted and monitored space heat consumption in RCDP houses. Specifically, this analysis will determine the degree to which SUNDAY predictions agree with monitored use; examine the correlations (if any) between the degree of agreement with such factors as house size, architecture, heating system type, and location; and determine which estimated SUNDAY inputs lead to the most consistent comparison between predicted and actual performance.

This analysis is separated into two primary sections. The first section contains descriptions of calculated and estimated SUNDAY input variables. This section also contains descriptions of methodologies used to collect and calculate physical inputs. The second section contains analysis of predicted and monitored performance including variables that are not included in the simulation model, but may impact energy consumption. 


\section{SUNDAY Input Variables}

\section{Conduction Heat Loss Coefficients}

Many complex inputs are required to perform a prediction of space heat energy consumption. This section describes methodologies used to calculate or estimate these inputs. Model variables include overall building heat loss coefficient, internal heat gains from people and appliances, structural heat storage capacity, intemal temperature set points and schedule, glazing orientation and transmissivity, and local weather. Overall building heat loss is broken into three components: conduction heat loss, mechanical convection heat loss, and natural convective heat loss.

Inputs that are either inaccurate or imprecise may negate any analysis of simulated performance. Effort has been made to ensure that the data do not contain systematic errors. However, due to fiscal and organizational constraints, compromises in the collection of data were necessary.

Standardized heat loss coefficients for wall, ceiling, and floor components were taken from a set of standardized U-values created for the Super Good Cents progrant and were calculated with standard ASHRAE procedures (Baylon and Heller, 1988). Basements were modeled with heat loss through the below grade walls and heat loss through the below grade slab. Heat loss coefficients for doors were assumed to be $0.33 \mathrm{Btu} / \mathrm{hr} \mathrm{ft}^{2}{ }^{\circ} \mathrm{F}$ and $0.19 \mathrm{Btu} / \mathrm{hr} \mathrm{ft}^{2}{ }^{\circ} \mathrm{F}$ for solid core wood and insulated metal doors, respectively.

Glazing heat loss coefficients were extracted from tested data available in the April 1987 Glazing Test Report List (Hogan, 1987). Windows were categorized by frame type, number of glazings, air space width, coating type, and filled gas type. Mean heat loss coefficients were then calculated for each category.

Component areas were examined for extreme values. Any extreme values were checked against construction blueprints and corrected if needed. A total of seven corrections were made. Three basement perimeter lengths and four glazing areas were incorrectly recorded and consequently corrected. Component areas and descriptions were extracted from house plans and were verified through a series of construction inspections. The methodology for collecting component data (plans check and inspection process) was similar to that used in the Residential Standards Demonstration Program and Cycle I of the Residential Construction Demonstration Project. This methodology was examined by the Washington State Energy Office (WSEO) and found to provide data that was accurate and relatively free from errors (Downey, 1988).

Overall conduction heat loss coefficient was calculated with Equation 1.

$$
U A_{c}=U_{1} A_{1}+U_{2} A_{2}+\ldots+U_{n} A_{n}+F_{s} P_{s}
$$

where:

$$
\begin{aligned}
& \mathrm{UA}_{\mathrm{c}}=\text { the overall conduction } \mathrm{UA} \text { in } \mathrm{Btu} / \mathrm{hr}{ }^{\circ} \mathrm{F} \\
& \mathrm{U}_{\mathrm{n}}=\text { the conduction heat loss coefficient for component } n \text { in } \mathrm{Btu} / \mathrm{hr} 3 \mathrm{~F}{ }^{\circ} \mathrm{F} \\
& \mathrm{A}_{\mathrm{n}}=\text { the area of component } \mathrm{n} \text { in } \mathrm{ft}^{2} \\
& \mathrm{~F}_{\mathrm{B}}=\text { the conduction heat loss coefficient for slab in } \mathrm{Btu} / \mathrm{hr} \mathrm{ft}{ }^{\circ} \mathrm{F} \\
& \mathrm{P}_{\mathrm{B}}=\text { the perimeter of slab in lineal feet }
\end{aligned}
$$

Table 2 contains summary statistics of the conductive heat loss coefficient calculated for the 120 homes examined in this analysis. Because different thermal standards were required depenting on the climate zone where the structure was located, Table 2 is cross tabulated by the three climate zones. Figure 1 contains histograms of these data. 


\begin{tabular}{|c|c|c|c|c|c|}
\hline Table 2 & \multicolumn{5}{|c|}{ Conduction Heat Loss Coefficients by Climate Zone } \\
\hline Lone. & n & Mean & Std Dev. & Min. & $\operatorname{Max}$ \\
\hline 1 & 57 & 318 & 76.2 & 181 & 518 \\
\hline 2. & 39 & 286 & 86.7 & 209 & 638 \\
\hline 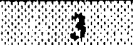 & 24 & 275 & 61.4 & 153 & 408 \\
\hline ail & 120 & 299 & 78.8 & 153 & 638 \\
\hline
\end{tabular}

\section{Figure 1}

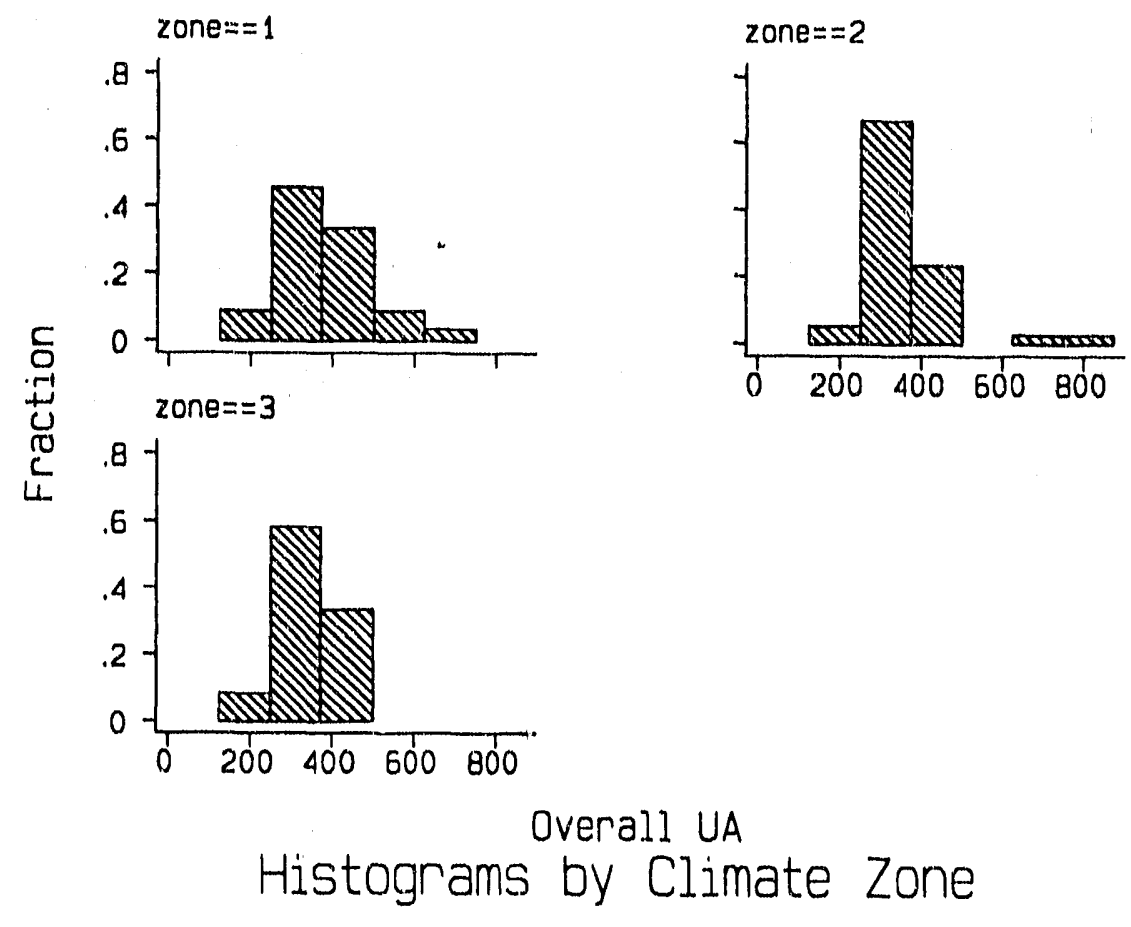

\section{Convection Heat Losses}

Convective losses are problematic for the simulation software used in this analysis since they can not be scheduled. Consequently convective heat loss must be condensed into an annual figure. Since all of the test homes were equipped with mechanical ventilation, convective heat loss is broken into two com ponents: mechanical and natural convective losses.

Mechanical Convection Losses. Each home in the program was equipped with ventilation systems. These included air-to-air heat exchangers, exhaust air heat pumps, and several alternative configurations of non-heat-recovery ventilation system.s. Two configurations of air-to-air heat exchangers were used: conventionally ducted and integrated into the ducting of a forced air heating system. All exhaust air heat pumps were the same model, the DEC Thermastor Products HPVAC. The non-heat-recovery systems are described in Table 3. 


\begin{tabular}{|c|l|c|c|c|}
\hline Table 3 & \multicolumn{3}{|c|}{ Mechanlcal Ventlation Systoms } \\
\hline System & \multicolumn{1}{|c|}{ Intake } \\
\hline AAHXc & $\begin{array}{l}\text { Air-to-air heat } \\
\text { exchanger } \\
\text { integrated with } \\
\text { heating system }\end{array}$ & Exhaust & No. of Homes & \% of Total \\
\hline AAHX & $\begin{array}{l}\text { Air-to-air heat } \\
\text { exchanger }\end{array}$ & 5 & 3.9 \\
\hline EAHP & $\begin{array}{l}\text { Through-wall } \\
\text { vents or make- } \\
\text { up air to forced } \\
\text { air heating } \\
\text { system }\end{array}$ & $\begin{array}{l}\text { Exhaust air heat } \\
\text { pump }\end{array}$ & 26 & 15.5 \\
\hline nHRV1 & $\begin{array}{l}\text { Through-wall } \\
\text { vents or central } \\
\text { ducted intake }\end{array}$ & $\begin{array}{l}\text { Designated } \\
\text { bathroom, } \\
\text { kitchen, or } \\
\text { laundry fan }\end{array}$ & 51 & 30.2 \\
\hline nHRV2 & $\begin{array}{l}\text { Through-wall } \\
\text { vents or central } \\
\text { ducted in-take }\end{array}$ & $\begin{array}{l}\text { Central ducted } \\
\text { exhaust }\end{array}$ & 15 & 13 \\
\hline nHRV3 & $\begin{array}{l}\text { Through-wall } \\
\text { vents or central } \\
\text { ducted intake }\end{array}$ & $\begin{array}{l}\text { Separate whole } \\
\text { house exhaust } \\
\text { fan }\end{array}$ & 6 & 4.7 \\
\hline nHRV4 & $\begin{array}{l}\text { Make-up air to } \\
\text { forced-air } \\
\text { heating system }\end{array}$ & $\begin{array}{l}\text { Designated fan, } \\
\text { whole house } \\
\text { fan, or central } \\
\text { exhaust }\end{array}$ & 44 & 29.5 \\
\hline
\end{tabular}

Heat exchanger air flow rates were measured at all fixed operating speeds during a single site survey conducted by Ecotope Inc. The field technician attempted to balance supply and exhaust flows during the site survey. In some instances the technician found it impossible to either measure flows or balance the HRV unit due to poorly located supply and exhaust vents, inaccessible flow dampers, or minimal flow capacity. Based upon inspection of the controls, Ecotope estimated the most probable flow rate for systems with multi-speed fans. Running time was recorded by hour meters-usually 120 VAC instruments connected across the fans. Sometimes a pressure switch and battery powered timer were used in heat recovery ventilators where access to internal wiring would have voided the UL label.

Mechanical convection losses were broken into two separate components: balanced convection losses and unbalanced convection losses. The former are simpler to deal with because they do not interact with natural ventilation. However, they only occur in the AAHX systems, which have supply air fans as well as exhaust fans.

Mechanical ventilation systems affect the heat loss coefficient (UA) of RCDP homes. To assess this relationship, weekly on-time readings were multiplied by the most likely tlow rate during operation. On-time instruments did not distinguish between various fan speeds. However, the control systems of multi-speed systems were usually configured so that high speed was only used for spot control less than an hour per day. Flows were measured at all fan speeds during the site visits. The flow used for assessing heat loss coefficient was based on the control system, and it was usually the low speed flow. 
Equation 2

Equation 3
Mechanical UA is complicated by the fact that some mechanical ventilators were heat recovery devices. Based upon findings from RCDP Cycle I, an adjustment factor of 40 percent was used in the UA equation for AAHXs because it was assumed that 60 percent of the exhaust heat energy was recovered. No measurements were made for AAHX effectiveness in this sample of houses.

EAHPs were handled differently, Much of their recovered heat went toward water heating rather than space heating. Also, their heat recovery rate is related to demand and is totally insensitive to outdoor temperature. Attempts to represent their heat recovery as a factor applied to ventilation UA would be inappropriate. EAHPs more than pay back all the heat lost by inducting outside air during mild weather, and indeed can provide a net gain over the year in milder climates. It should also be remembered that all their input energy is recorded as water heating due to the sub-meter wiring. In summary, SUNDAY should tend to over-predict EAHP houses because it does not account for their heat recovery, ard the metered space heat does not include some of the electric energy used for heating.

Mechanical ventilation UA was computed using Equation 2.

$$
\begin{aligned}
& \text { Mech } U A=a d j \cdot \text { exflow } \cdot \text { verdav } / 24 \cdot C_{p} \cdot 60 \cdot \rho \cdot\left(1-\text { stieclev } \cdot 3.458 \times 10^{-5}\right) \\
& \text { where: } \\
& \text { Mech UA }=\text { Mechanical heat loss coefficient in Btu/hr/ } /{ }^{\circ} \mathrm{F} \\
& \text { exflow }=\text { Exhaust flow rate during on time in } \mathrm{ft}^{3} / \mathrm{min} \\
& \text { vperday }=\text { Average on time in hr/day } \\
& \text { siteelev }=\text { Site elevation in } \mathrm{ft} \\
& \mathrm{C}_{\mathrm{p}} \quad=\text { Specific Heat of air }=.24 \mathrm{Btu} / \mathrm{bm} /{ }^{\circ} \mathrm{F} \\
& \rho=\text { Density of air at sea level \& } 530 \mathrm{R}=0.0748 \mathrm{lbm} / \mathrm{ft}^{3} \\
& \text { adj = Adjustment factor }=0.4 \text { for AAHX's, otherwise } 1.0
\end{aligned}
$$

Natural Convective Losses. The natural ventiation !osses were determined by using blower door testing and then using a computer model developed by Lawrence Berkeley Laboratories (LBL) to predict natural infiltration (Sherman and Grimsrud, 1980). The Ecotope Inc. analysis found that the model significantly over-predicted the effects of wind (Palmiter, Brown, and Bond, 1989). Indeed the stack effect part of the model, used alone, gave a much better correlation with infiltration measured by tracer gas testing. Average wind speed during the test was low, only $3.7 \mathrm{Mph}$. Therefore, this analysis used the stack model results as the natural infiltration predictor for computing UA. The LBL model used weather data as an input because wind speed and temperature differential affect ventilation. Ideally, this should have been actual year weather data. However, other uses for the ventilation data required typical meteorological year data be used.

UA from natural ventilation was computed using Equation 3.

$$
\begin{aligned}
& \text { Nat UA }=A C H_{s t} \cdot \text { vol } \cdot C_{P} \cdot \rho \cdot\left(1-\text { siteelev } \cdot 3.458 \times 10^{-5}\right) \\
& \text { where: } \\
& \text { Nat UA }=\text { Natural Infiltration heat loss coefficient in Btu/hr } /{ }^{\circ} \mathrm{F} \\
& \mathrm{ACH}_{\mathrm{Bt}}=\mathrm{ACH} \text { computed by the LBL stack model } \\
& \text { vol }=\text { House volume in } \mathrm{ft}^{3} \\
& \text { siteelev }=\text { Site elevation in } \mathrm{ft}
\end{aligned}
$$




$$
\begin{array}{ll}
\mathrm{Cp} & =\text { Specific Heat of air }=.24 \mathrm{Btu} / \mathrm{lbm} / \mathrm{oF} \\
\rho & =\text { Density of air at sea level \& } 530 \mathrm{R}=0.0748 \mathrm{lbm} / \mathrm{ft}^{3}
\end{array}
$$

For AAHXs only, the mechanical and natural ventilation were simply summed. This would overstate the combined ventilation in exhaust-only houses. Negative pressure induced by exhaust-only systems eclipses part of the natural exfiltration. The degree of eclipsing varies with time, depending upon temperature differential and the amount of induced negative pressure.

In the past, popular convention has been to compute total ventilation by adding unbalanced mechanical flow and natural ventilation in quadrature. This method was probably inspired by the knowledge that wind and stack induced pressure differentials are additive, and their resulting infiltration varies roughly as the square root of pressure differential across any leakage areas. Adding in quadrature is inappropriate when combining natural ventilation with mechanical because the mechanical impetus is a constant flow phenomenon. Fans exhaust through a dedicated port at a rate nearly independent of other wind and stack driving forces. The currently favored method for combining the two involves adding half the mechanical flow to the natural flow during hours of operation. This method was used in this study. The rationale and exact implementation of this is discussed in greater detail in a separate publication (Douglass, 1991).

Nine houses had faulty or missing mechanical ventilation or blower door data. In these cases, the UA was computed from defaults used in the code compliance software, WATTSUN.

The total heat loss coefficient for each structure is composed of conductive heat loss, mechanica' entilation heat loss, and natural convective heat loss. Equation 4 represents this figure. The mean heat loss coefficient per square foot of heated space was calculuted for structures in each of the three climate zones. Table.$\downarrow$ summarizes these data.

$U A_{t}=U A_{c}+U A_{v}$

where:

$\begin{array}{ll}\mathrm{UA}_{\mathrm{c}} & =\text { Overall conduction UA in Btu/hr/ }{ }^{\circ} \mathrm{F} \\ \mathrm{UA}_{\mathrm{v}} & =\text { Combined natural and net mechanical UA in } \mathrm{Btu} / \mathrm{hr} /{ }^{\circ} \mathrm{F}\end{array}$

\section{Table 4} Overall Heat Loss Coefficlent per Square Foot

\begin{tabular}{|c|c|c|c|c|c|}
\hline 2ons & n & Mean & Std Dev. & Min. & Mar: \\
\hline 1 & 57 & 379 & 99.4 & 232 & 677 \\
\hline 2 & 39 & 362 & 116.5 & 234 & 872 \\
\hline 3 & 24 & 341 & 73.4 & 202 & 484 \\
\hline 111 & 120 & 366 & 101.2 & 202 & 872 \\
\hline
\end{tabular}
for 120 Homes by Cllmato Zone (Btu/hr/pF)

Figure 2 is a percentage cluster pie chart representing the contribution of conduction, natural infiltration, and net mechanical ventilation to the total heat loss coefficient. While natural infiltration was approximately equal to expected values for each heat loss category, mechanical ventilation was used consistently less. Most mechanical ventilation systems had the capacity to adequately ventilate the homes, but systems were operated far less than had been hoped. Figure 3 contains a histogram by climate zone of average mechanical ventilation system on-time for the 120 houses. 


\section{Flgure 2}

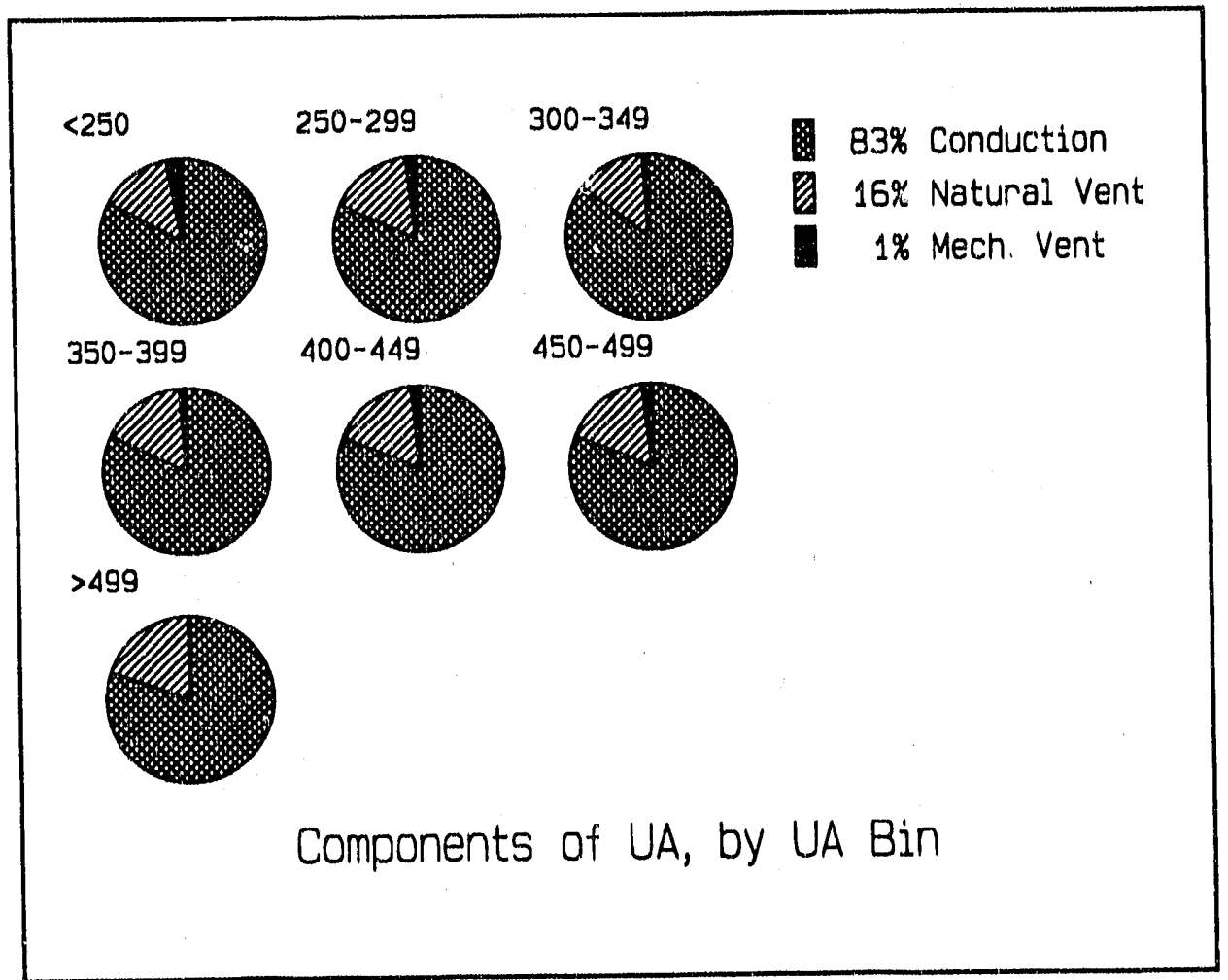

Figure 3

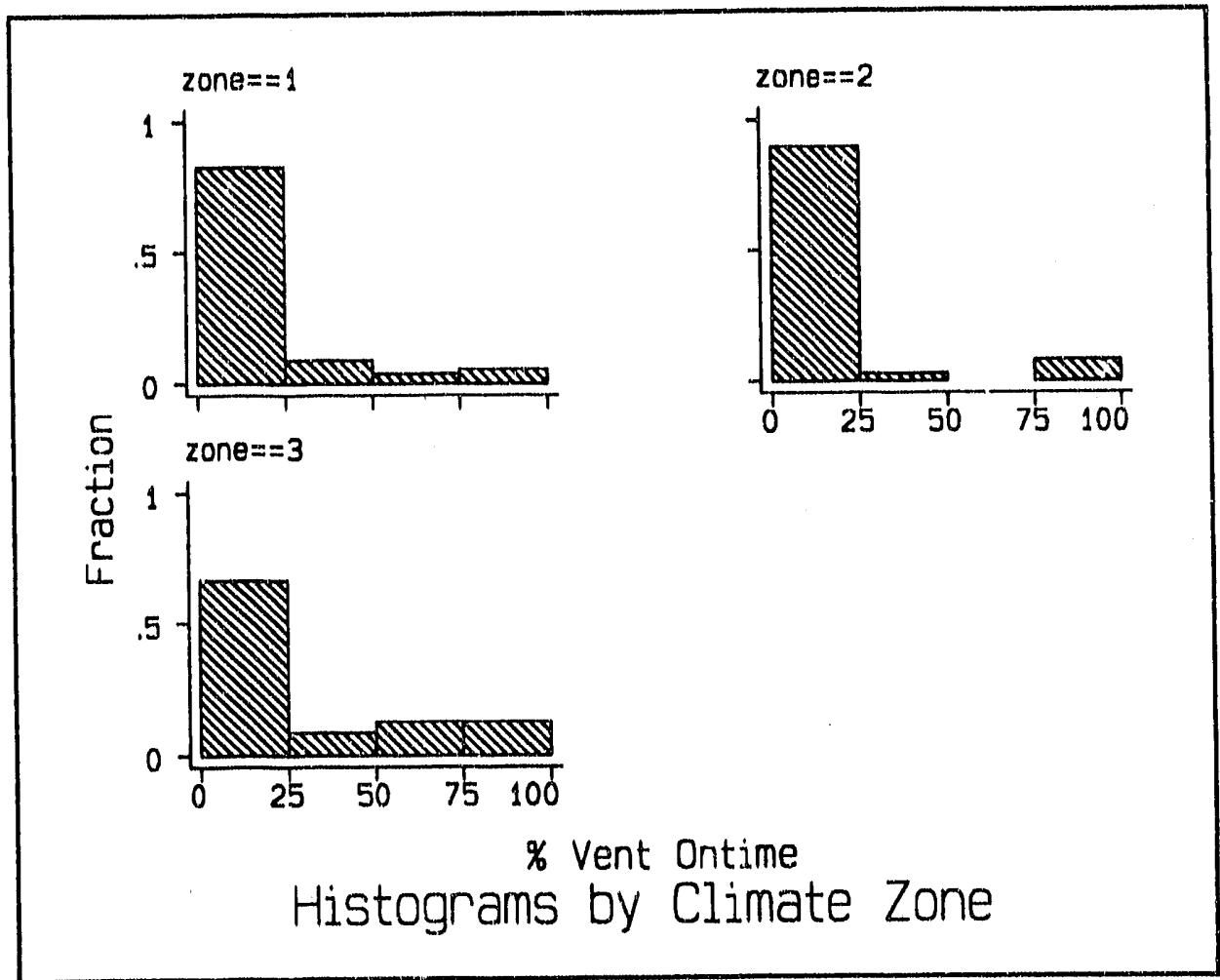


Structural heat capacity was modeled assuming three types of construction: light frame (crawlspace); slab on grade; and basement construction. l.jight frame construction was assumed to contain $3.0 \mathrm{Btu} /{ }^{\circ} \mathrm{F} \mathrm{ft}^{2}$; slab construction was assumed to contain 7 $\mathrm{Btu} /{ }^{\circ} \mathrm{F} / \mathrm{ft}^{2}$; and homes with below grade walls were assumed to contain $11 \mathrm{Blu} /{ }^{\circ} \mathrm{F} / \mathrm{ft}^{2}$ (Ecklund and Baylon, 1984). Homes with more than one story that were built on a slab or basement were modeled with a combination of construction types. Table 5 describes different construction types found in the data set and their associated structural heat capacity. Crawlspace homes have been further broken into two categories: vented and unvented. Basement homes have been further separated into full and daylight basements.

\section{Table $5 \quad$ Structural Heat Capacity In Btu/ ${ }^{\circ} \mathrm{F}$}

\section{Thermostat Sot Point}

\section{Internal Heat Gains}

\begin{tabular}{|c|c|c|c|c|c|}
\hline $\begin{array}{l}\text { Type of } \\
\text { Foundation }\end{array}$ & in & Mean & Std, Dev. & Min. & Max. \\
\hline Vented & 50 & 5797 & 2876 & 2766 & 22560 \\
\hline Unvented & 9 & 4994 & 1419 & 3912 & 7995 \\
\hline Slab & 10 & 7475 & 2469 & 4000 & 13656 \\
\hline Bosement & 15 & 14864 & 5073 & 8064 & 25344 \\
\hline oaylight & 34 & 11380 & 6809 & 3948 & 38976 \\
\hline Onknown & 2 & 4417 & 638 & 3966 & 4868 \\
\hline Total & 120 & 8569 & 5633 & 2766 & 38976 \\
\hline
\end{tabular}

Daytime and nighttime thermostat set points were acquired from weekly occupant reporting cards. There were no temperature recorders in the Cycle II houses, so these could not be verified. These settings compare very closely to the Cycle I themostat settings. The latter were obtained from the occupant survey since Cycle I occupants were not required to indicate weekly settings. In Cycle II, the day setting mean was $68.5^{\circ} \mathrm{F}$ with a standard deviation of $3.5^{\circ} \mathrm{F}$. The night setting mean was $63.7^{\circ} \mathrm{F}$ with a $6.2^{\circ} \mathrm{F}$ standard deviation. Duration of nighttime sethack was assumed to be 10 hours.

Many occupants indicated that the thermostat was set "off" at night. In most sites this was reported during milder weather with a specific setback reported during colder weather, In these cases SUNDAY (which accepts only one setback temperature for the entire year) was given the setback used in colder weather. An "off" setting in milder weather would have little effect on actual space theat. In this sample of low UA houses during milder months, indoor temperature floats down only a few degrees over night. This would rarely be enough to initiate nighttime heating during setback hours, so whether the thermostat was set back or "off" is moot.

Heat gains from appliances and occupants offset the need for space heat. SUNDAY requires that an hourly average internal heat gain be specified. This figure cannot be scheduled. The methodology used to calculate internal gains was identical to that used in the analysis of RSDP and RCDP Cycle II data (Byers and Palmiter, 1988; Downey, 1989). Average hourly internal heat gains were estimated from appliance load, appliance type, and the number of people in the structure. Equation 5 was used to calculate hourly internal heat gains and is derived from appliance performance estimates. 
where:

$\begin{array}{ll}\mathrm{I} & =\text { Internal beat gains in Btu/hr } \\ \mathrm{S} & =\text { metered space heat in } \mathrm{kWh} / \mathrm{yr} \\ \mathrm{DHW} & =\text { metered domestic water heat in } \mathrm{kWh} / \mathrm{yr} \\ \mathrm{W} & =\text { the number of well pumps } \\ \mathrm{R} & =\text { the number of refrigerators located outside } \\ \mathrm{F} & =\text { the number of freezers located outside } \\ \mathrm{P} & =\text { the number of occupants } \\ \mathrm{H} & =\text { the number of water heaters }\end{array}$

The factor of 80 percent is applied to account for electrical appliance use outside the heated space in addition to those appliances explicitly accounted for in the equation. This figure is arbitrary and may introduce systematic bias into the analysis, but it is the same figure used by Byers and Palmiter, and Downey. Internal gains are summarized in Table 6 by UA category.

Glazing Orientation and Transmittance

\author{
Weather Data
}

\section{Simulation Results}

\section{Table $6 \quad$ Average Internal Gains by UA Category (Btu/hr)}

\begin{tabular}{|c|c|c|c|c|c|}
\hline bia & n & Mosm & Std. Dev. & Mau. & Mos \\
\hline$<250$ & 9 & 2502 & 1000 & 1083 & 3690 \\
\hline 230,209 & 15 & 2611 & 571 & 1389 & 3666 \\
\hline 300349 & 37 & 2810 & 1094 & 1031 & 6470 \\
\hline 350,390 & 26 & 2949 & 1001 & 1245 & 4745 \\
\hline $400-449$ & 17 & 2654 & 941 & 1125 & 4502 \\
\hline 450,459 & 7 & 3625 & 1592 & 2123 & 6931 \\
\hline$>499$ & 9 & 4139 & 2157 & 1820 & 7668 \\
\hline Total & 120 & 2921 & 1195 & 1031 & 7668 \\
\hline
\end{tabular}

Glazing areas were extracted from construction blueprints. Orientation was also taken from blueprints when possible, or was extracted from the solar site survey completed during the site visit by contracted technicians. SUNDAY requires that each window have a solar multiplier that accounts for glazing transmissivity. For the purposes of this analysis, the solar multiplier for double pane and triple pane windows were 0.95 and 0.85 , respectively. This assumes no shading from overhangs or vegetation.

Required SUNDAY weather inputs include daily average temperature, available insolation, and hours of daylight. Temperature data were constructed from actual daily maximum and minimum temperature recordings taken during the study period for 39 locations throughout the Pacific Northwest. These were processed into average daily temperatures with a cosine interpolation algorithm. Insolation data were not recorded at each locality, but were taken directly from typical meteorological year data (TMY) and are may not be representative of real insolation levels experienced by these homes. Hours of daylight were calculated with algorithms outlined in Lunde (1980).

All of the variables discussed above were used as inputs into the simulation mojei. Space heat was simulated for 120 homes and is compared to monitored energy 
consumption in Figure 4. A least squares regression analysis of these data indicated that 43.8 percent of the variation in monitored space heat is explained by the simulated data. Before beginning the analysis, all homes with evidence of bad data were excluded. For example, one excluded coastal home had a very low predicted space heat because the occupant consistently indicated that the normal daytime thermostat setting was $55^{\circ} \mathrm{F}$. The actual space heat in conjunction with weather data suggests that an ordinary settiag closer to $70^{\circ} \mathrm{F}$ was much more probable. Other houses were excluded because it was known that the occupants burned wood.

\section{Flgure 4}

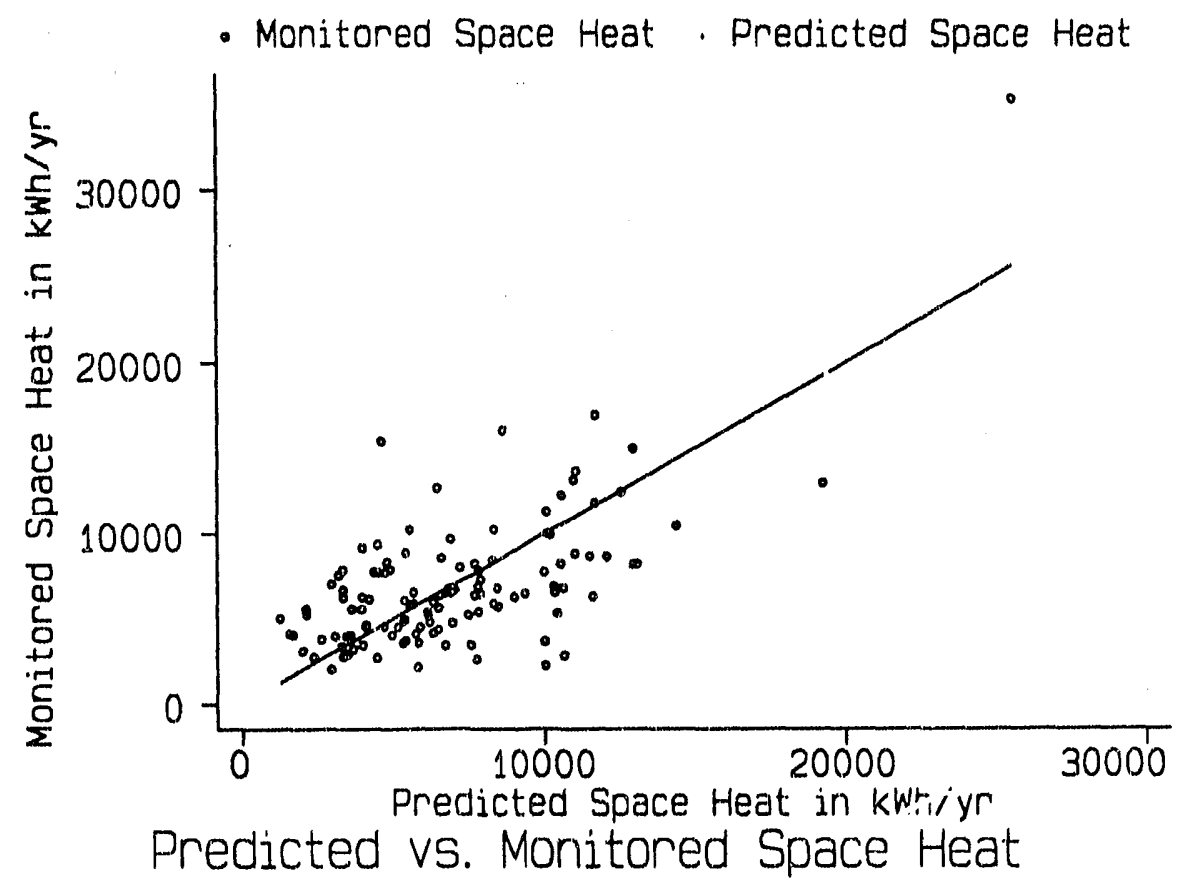

Unusual systern configurations, extremes in archirecture, extended vacations, and a broad range of occupant behavior have been observed in RCDP Cycle II, as in all the residential demonstration projects. These unique conditions exist over a range of extremity and it wa ${ }^{\prime}$ not easy to decide which were sufficiently unconventional to warrant exclusion. It was decided to maintain objectivity at some cost in precision, by minimizing the number of excluded houses. If no evidence of faulty data was found, houses were not excluded just because of a large mismatch between predicted and monitored.

Monitored and predicted space heat were categorized by heat loss coefficient bin as summarized in Table 7. Differences between means of monitored and predicted space heat were examined with paired $t$ tests for each category and two were significantly different than zero (probability). The greatest difference and greatest significance is the 25 percent over-prediction of the 300 to 349 bin. This was also the greatest over-predicted bin in the RCDP Cycle I analysis ( 16 percent over), although it was not shown to be statistically significant (probability was 0.1 ). This was the largest bin (i.e. contained the most houses) in both cycles of RCDP. These data are represented visually in Figure 5. 


\section{Table 7 Monitored vs. Predicted Space Heat by UA Bin}

\begin{tabular}{|c|c|c|c|c|c|c|}
\hline btu/ks/or & n & $\begin{array}{l}\text { Monitored } \\
\text { BWh/st }\end{array}$ & $\begin{array}{l}\text { Predicted } \\
\mathrm{KWh} / \mathrm{r}\end{array}$ & $\begin{array}{l}\text { Differencce } \\
\mathbf{k W h} / \mathbf{y r}\end{array}$ & $\begin{array}{l}\text { Ratio } \\
\mathbf{P} / \mathbf{M}\end{array}$ & $\begin{array}{l}\text { Patred } t \\
\text { Probability }\end{array}$ \\
\hline$<250$ & 9 & 4,788 & 3,322 & 1,466 & .69 & .04 \\
\hline 250,209 & 15 & 5,484 & 4,177 & 1,306 & .76 & .07 \\
\hline $300-349$ & 37 & 5,397 & 6,767 & $-1,371$ & 1.25 & .00 \\
\hline 350,399 & 26 & 7,374 & 7,168 & 206 & .97 & .71 \\
\hline 400.449 & 17 & 6,934 & 7,512 & -578 & 1.08 & .30 \\
\hline $450,499^{\circ}$ & 7 & 10.297 & 9,730 & 567 & .94 & .78 \\
\hline 1499 & 9 & 13,764 & 11,596 & 1,768 & .87 & .35 \\
\hline Total & 120 & 6,922 & 6,942 & -21 & 1.00 & .94 \\
\hline
\end{tabular}

\section{Figure 5}

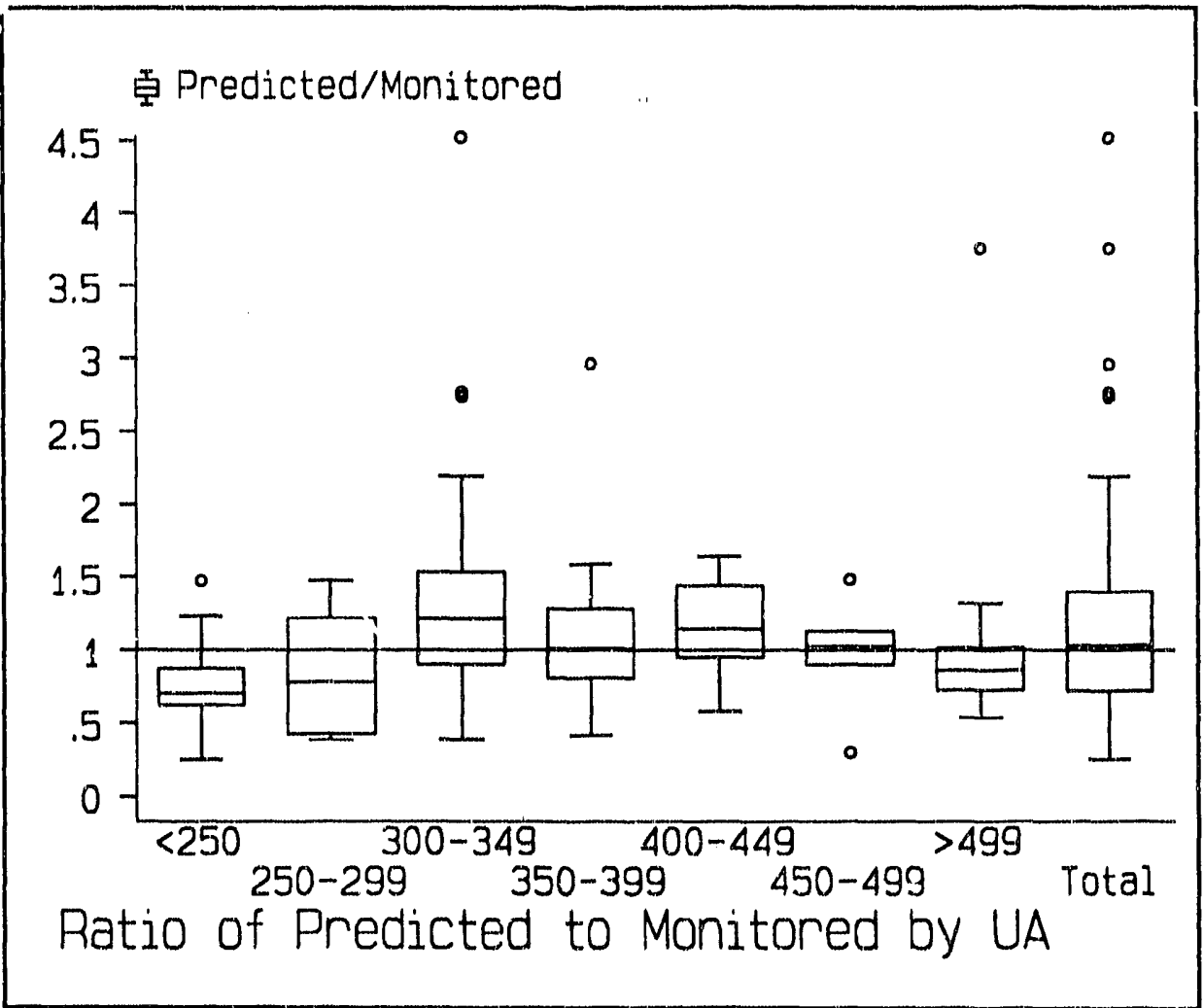

It is common knowledge that different electric heating systems vary in their energy usage. Several things can explain this. Systems with zonal control reduce energy usage by allowing some areas of the house to be kept cooler when unoccupied. Heat pumps augment electric energy input with a vapor cycle machine that actually "pumps" heat from the outdoor environment into the house. Conversely, ducted systems are vulnerable to energy losses througn leaks because of room pressurization. Also, whenever ducts are routed outside the heated space, additional surface area of the ducts themselves is vulnerable to leakage and cunduction losses. 
SUNDAY treats all electric resistance heating systems equally and uses a default HSPF of 6.8 for heat pumps. In this analysis, the heat pump HSPF was adjusted by a factor of 0.87 to be consistent with WATTSUN, which has been given this default factor, based upon experience, to account for duct losses.

Figure 6 illustrates how the different heating systems compared. The last two boxes, electric furnaces and heat pumps, were the only ducted systems. The other nonducted systems vere usually zone controlled. Electric furnaces used a mean of 16 percent more heating enurgy than SUNDAY predicted, but this is inconclusive because there were only 10 in the sample population. With the 0.87 adjustment, SUNDAY predicted heat pump houses to use 6 percent more than was monitored; unadjusted, the prediction would have been 9 percent below that monitored. Radiant heated houses (mostly radiant slab) were too few to ascribe any meaning to the results.

\section{Flgure 6}

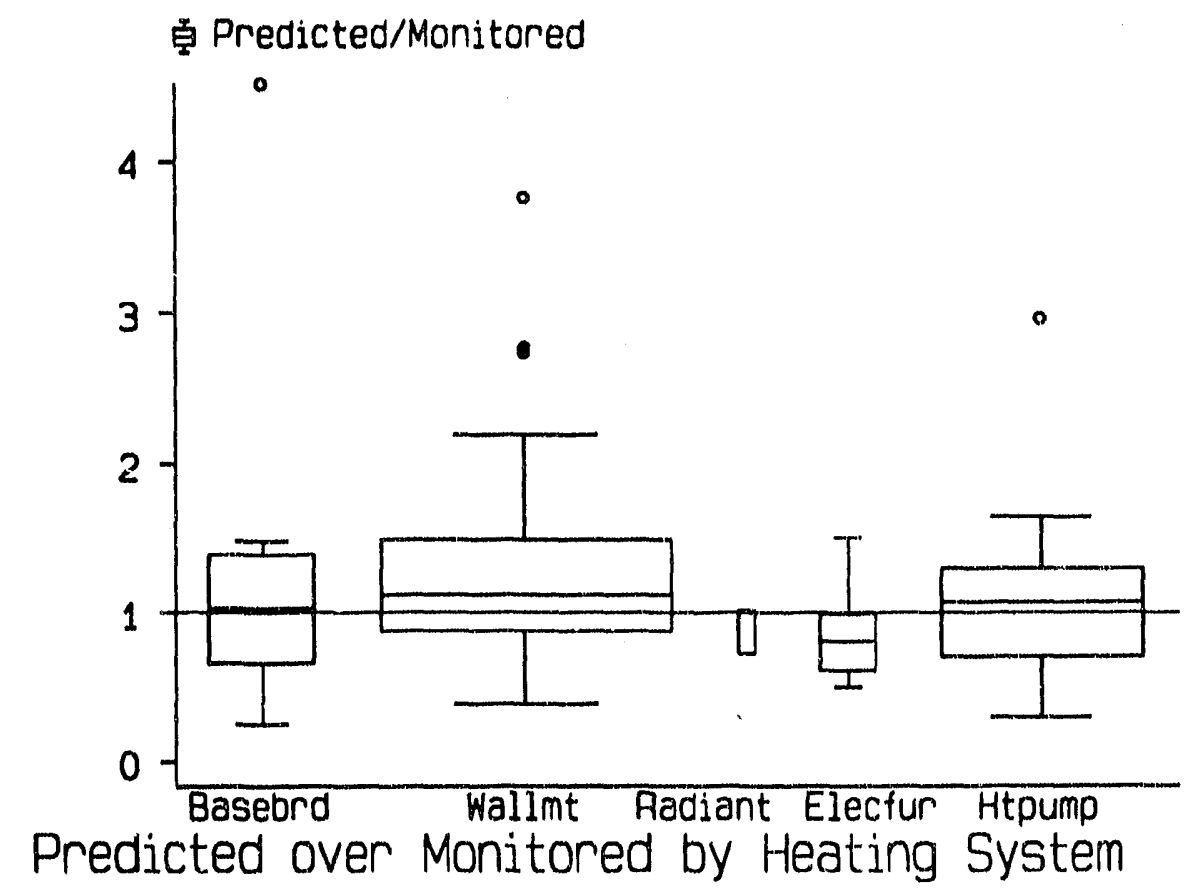

Several variables known to impact space heat energy consumption are not included in the simulation model. The simulation model does not include heating system efficiency or house type- both of which have been shown by other researchers to affect space heat energy consumption (Byers and Palmiter, 1988). House size (conditioned floor area) is another variable that is not explicitly included in the simulation model but has been correlated with space heat. However, house size is positively correlated to heat loss coefficient, heat capacity, and internal heat gains-all of which are included in the simulation model

An analysis of covariance model was used to examine those factors that are not explicitly included in the simulation model. Predicted space heat and house size were include as continuous variables and categorical variables were created for heating system type and house type. Heating systems were categorized as electric furnace, radiant, zonal, baseboard, and heat pump systems. House type was categorized by number of stories. A 
separate variable classified foundation types as venied crawlspace, unvented crawlspace, slab on grade, daylight basement, or full basement.

There was considerable interest in SUNDAY's ability to predict accurately with the new ventilation systems, especially non heat recovery systems used in RCDP Cycle II. As indicated in Figure 7, there was no significant difference between the heat recovery and non heat recovery systems. This is not surprising given the low on time, thus small contribution to whole house UA made by the ventilation systems.

\section{Flgure 7}

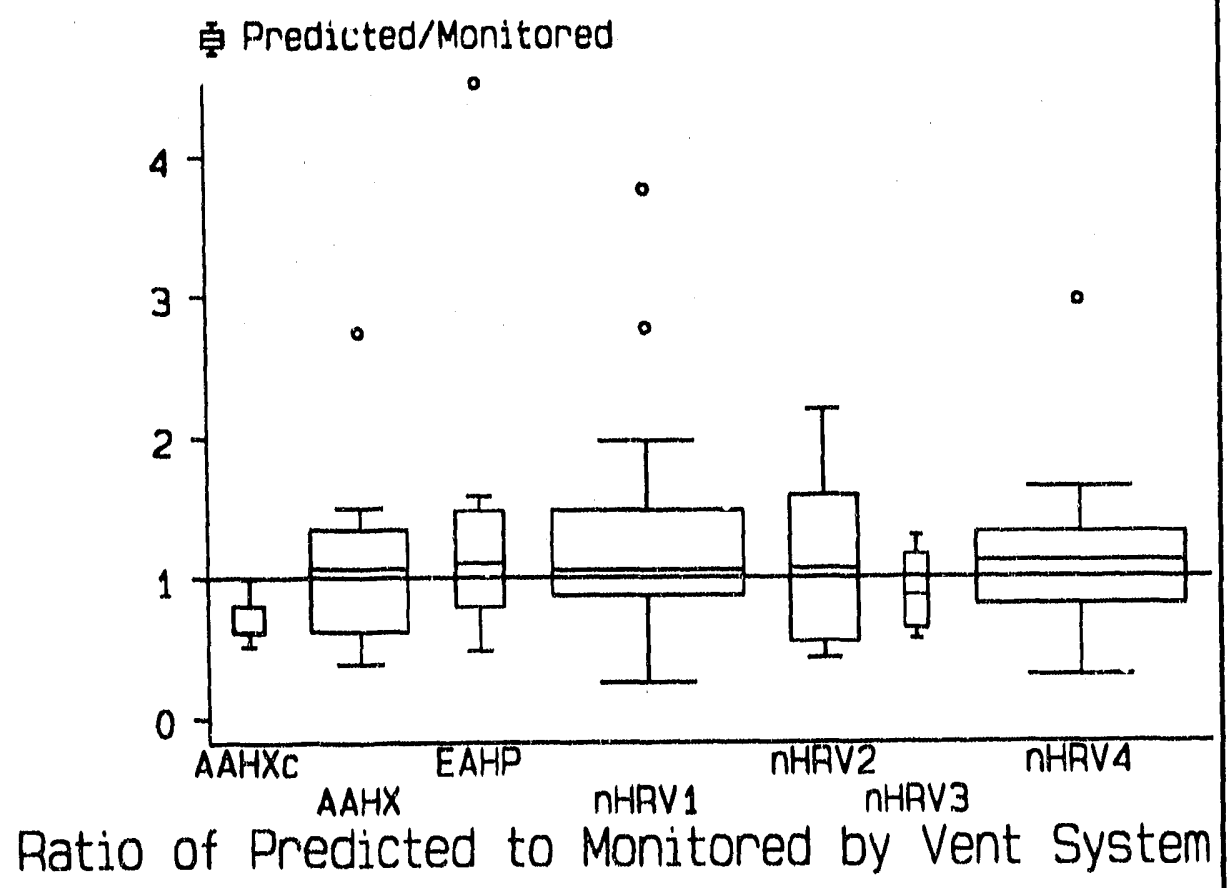

Other variables that were included in the simulation and were also examined with the analysis of covariance model included total UA, mass, intemal gains, and effective solar glazing area. None of these variables, which were explicitly included in the SUNDAY model, were significant either by themselves or interacted with predicted space heat in the analysis of covariance model. This would suggest that the SUNDAY model adequately explained variation in energy consumption due to these variables.

Modification of the predicted space heat with this analysis of covariance model increases the coefficient of determination from 0.438 to $0.670 ;$ a 54 percent increase.

$$
\begin{aligned}
& \begin{array}{ll}
S_{m}=1.487 h+(a+b) & S_{p}+899.1 \\
\text { where: } & =\text { Modified Sunday predicted spaceheat in } \\
S_{m} & =\text { Sunday predicted space heat in } \mathrm{kWh} / \mathrm{yr} \\
S_{p} & =\text { House floor area in square feet } \\
h &
\end{array}
\end{aligned}
$$


a

$$
\begin{array}{ll}
\text { baseboard } & =0.085 \\
\text { wall mount } & =-0.157 \\
\text { radiant } & =0.474 \\
\text { electric fumace } & =0.183 \\
\text { heat pump } & =0.085 \\
\text { vented crawlspace } & =0.475 \\
\text { basement } & =0.354 \\
\text { slab on grade } & =0.440 \\
\text { daylight basement } & =0.443
\end{array}
$$

b

= Heating System Type

foundation type

The predicted is compared to modified predicted in the paired box plot of Figure 8 . Most outliers are brought in considerably, but more importantly the span of the second and third quartiles are also shrunk.

\section{Flgure 8}

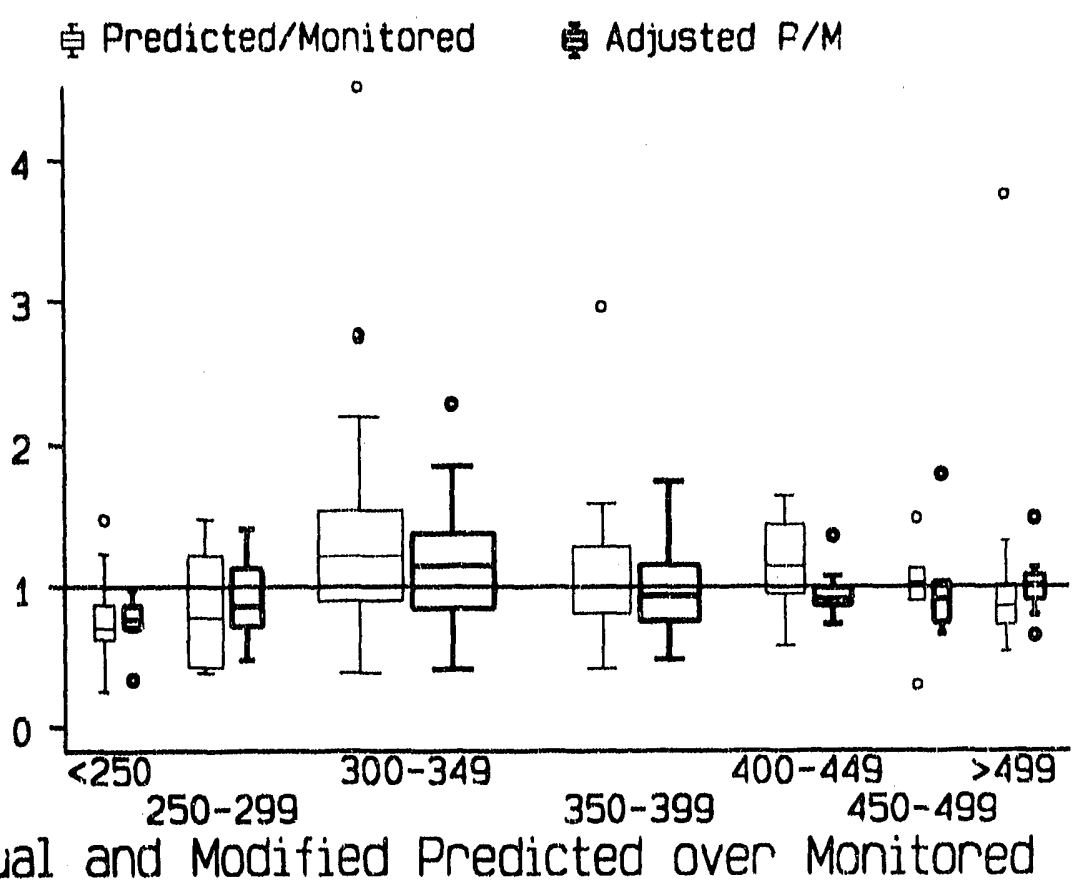

As conservation standards increase, it is reasonable to ask if SUNDAY remains accurate. To investigate this, an index of conservation robustness was created. This involved simply normalizing whole house UA to conditioned floor area. By definition, houses with lower UA per square foot were more robust. The ratio of predicted to monitored was essentially constant across the bins of robustness. This sample provides no suggestion that the accuracy of SUNDAY is biased in either direction for houses with higher conservation levels. 
The SUNDAY thermal simulation program was used to predict space heat energy consumption for 120 energy efficient homes. The predicted data were found to explain 43.8 percent of the variation in monitored space heat consumption. Using a paired Student's 1 test, no statistically significant difference could be found between mean predicted space heat and monitored space heat for the entire sample of homes. The homes were grouped into seven classes, sub-samples by total heat loss coefficient. An intermediate class (UA $=300-350 \mathrm{Btu} /{ }^{\circ} \mathrm{F}$ ) was found to significantly over-predict space heat by 25 percent. The same class was over-predicted by 16 percent in the analogous Cycle I research, but the sample size was smaller and this was not found to be statistically significant.

Several variables that were not directly included as inputs to the simulation were examined with an analysis of covariance model for their ability to improve the simulation's prediction of space heat. The variables having the greatest effect were conditioned floor area, heating system type, and foundation type. The model was able to increase the coefficient of determination from 0.438 to $0.670 ;$ a 54 percent increase.

While the SUNDAY simulation program on aggregate is able to predict space heat consumption, it should be noted that there is a considerable amount of variation in both the monitored space heat consumption and the SUNDAY predictions. The ability of the program to accurately model an individual house will be constrained by both the quality of input vartables and the range of occupant behavior. These constraints app $y$ to any building model. 
Baylon, D. and J. Heller. Super Good Sents Heat Loss Reference Volumes I and II. Eootope Ind., Seattle, Washington. Frepared for the Bonneville Power Administration. October 1988

Ryers, R. and L. Palmitex. Analysis of Agreement between Predicted and Monitored Annual Space Heat Use for a Large Sample of Homes in the Pacific: Northwest. Amietican Council for an Energy Efficient Economy (ACEEE), Summer Study on Energy Efficiency in Buildingss. August 1988.

Douglass, J.G. Residential Construction Demonstration Project Cycle Il; Active Ventilation. Washington State Eneigy Otfice, Olympia, Washington, Pnepared for the Bonneville Power Adrnirdstration. February 1991.

Downey, P.K. Restdential Standards Demonstration Program Case Sifudiss. Washington State Energy Office, Olympla, Washington. Prepared for the Bonreville Power Administration. September 1.988.

Downey, P.K Analysis of Predicted vs. Monitored Space hear Energy Use in 8.3 Homes. Washington State Energy Office, Olympia, Washington. Prepared for the Bunneville Power Administration. August 1989.

Ecklund, K. and D. Baylon. Design Tools for Energy Efficient Homes. Third Edtion. Ecotope Hic., Seattle, Washingtora. Aprid 1984.

Emory, A., Heerwagen, D., Heerwagen J., Kippenhan, C., and Varey, O. 1989. Dynamic Response of Building Components in Residentiol. Homes: Simulation Report, University of Washington report to the Washington State Energy Office under Contract \#86-34-02. January, 1989.

Hogan, J. April 1987 Glazing Test Reports List. Seattle Department of Construction and Land Use, Seattle, Washington. April 1987.

Lunde, P.J. Solar Thermal Engineering: Space Heating and Hot Water Systems. Jon Wiley \& Sons, Inc., New York, New York. 1980.

Sherman, M.H. Estimation of Infiltration from Leakage and Climate Indicators, Law. rence Berkeley Laboratory, Berkeley, California. December 1986.

yoder, R. Comparison of Sunday - Predicted and Monitored Space Hert Energy Use. Draft Report. Hood River Project Pacific Power and Light, Portland, Oregon. January 1987. 

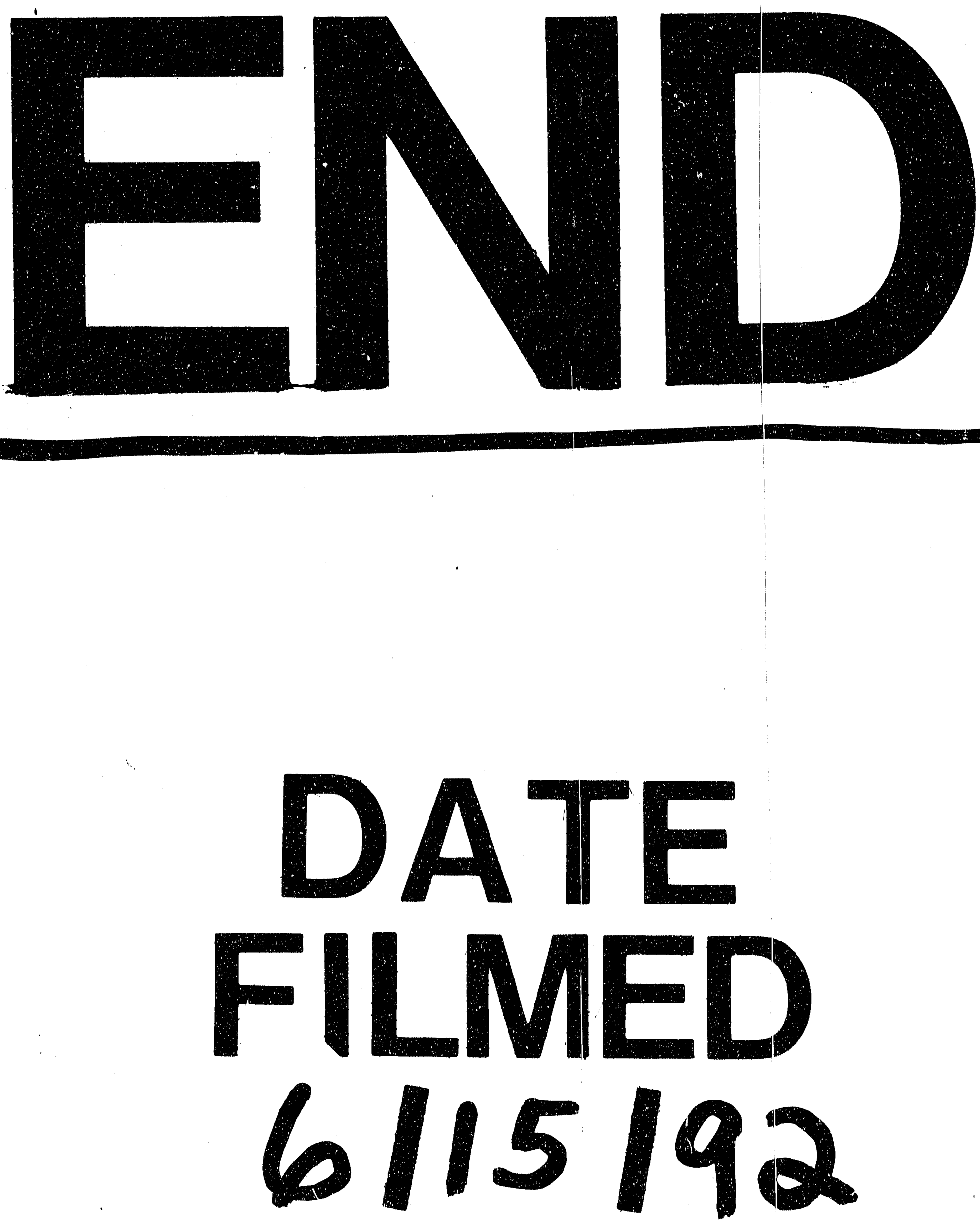
